\title{
Surgical Site Infection in A Tertiary Centre In Nigeria
}

\author{
Dodiyi-Manuel Amabra. (Mbbs,Fwacs), \\ *Dodiyi-Manuel Sotonye T. (Mbbs, Fwacp \\ (Department Of Surgery, University Of Port Harcourt Teaching Hospital, *Department Of Internal Medicine, \\ University Of Port Harcourt Teaching Hospital).
}

\begin{abstract}
:
Background: Surgical site infection (SSI) previously called wound infection is defined as that infection presenting up to 30 days after a surgical procedure if no prosthesis is placed and up to 1 year if a prosthesis is implanted in the patient.It has been reported to be second only to urinary tract infection as the commonest hospital acquired infection and actually the most commonly encountered form of nosocomial infection in surgical practice. The commonest organisms causing SSI have been reported to be gram positive cocci and gram negative bacilli.

Aim: To identify the risk factors of SSI together with the identification of the aetiological bacterial agents. Patients And Methods: This is a 3 year prospective study conducted at the University of Port Harcourt Teaching Hospital (UPTH) between $1^{\text {st }}$ July, 2013 and $30^{\text {th }}$ June, 2016.

All patients with SSI were recruited for the study. Data which included age, sex, duration of surgery, type of surgical wound, nature of operation (elective of emergency), body mass index (BMI), site of operation, organisms isolated and associated risk factors ( e.g diabetes) were obtained and recorded on a data sheet. Data were analyzed using the Statistical Package for Social Sciences (SPSS) version 16. Chi square $\left(x^{2}\right)$ and Fisher's exact tests were used to observe associations. $P$ value of $<0.05$ was considered statistically significant. Results: There were 32 cases of surgical site infection out of the 350 surgeries within the study period and this constitutes about $9.1 \%$. There were $20(62.5 \%)$ males and 12 females (37.5\%) with a male to female ratio of 1.7:1. Their ages ranged from 27 to 65 years with a mean of 40.4 \pm 3.7 years and the most commonly affected age group was 21-30 years. Significant risk factors included emergency operation, prolong surgeries ( > 2 hours), dirty wounds and obesity. There was no significant association between SSI and diabetes. Conclusion: The rate of SSI was $9.1 \%$ and the identified risk factors were emergency operations, dirty wounds, long duration of surgery (>2 hours) and obesity. The commonest organism isolated was Klebsiella.
\end{abstract}

Keywords: Surgical site infection, Tertiary, Nigeria.

\section{Introduction}

Surgical site infection (SSI) previously called wound infection is defined as that infection presenting upto 30 days after a surgical procedure if no prosthesis is placed and up to 1 year if a prosthesis is implanted in the patient ${ }^{1}$. In the United States, SSI is found to be a serious complication with an incidence of 2 to $5 \%$ in patients undergoing surgery ${ }^{2}$ while in Nigeria, it was found to be 9.4 and $9.1 \%$ at Ibadan and Kano respectively $y^{3,4}$. SSI has been reported to be second only to urinary tract infection as the commonest hospital acquired infection and actually the most commonly encountered form of nosocomial infection in surgical practice ${ }^{5}$. It results in patients' discomfort, prolong length of hospital stay and increased $\operatorname{cost}^{6}$. The risk of developing SSI is affected by many factors which may include degree of microbial contamination of the operation site indicated by class of wound (i.e clean, clean contaminated, contaminated and dirty), age of patient, duration of surgery, pre operative shaving of the operation site and co-morbidities like diabetes ${ }^{7}$. It has been reported that the majority of organisms causing SSI are gram positive cocci e.g staphylococcus aureus and gram negative bacilli e.g E.coli, Klebsiella, pseudomonas and enterobacter specie ${ }^{2,8}$. However, the most significant change in the microbiology of SSI has been the increased involvement of resistant organisms like Methicillin Resistant Staphylococcus Aureus (MRSA).The aim of this study is to identify the risk factors of SSI together with the identification of the aetiological bacterial agents.

\section{Patients And Methods}

This is a 3 year prospective study conducted at the University of Port Harcourt Teaching Hospital between $1^{\text {st }}$ July, 2013 and $30^{\text {th }}$ June, 2016.All patients with SSI were recruited for the study. Data which included age, sex, duration of surgery, type of surgical wound, nature of operation (elective of emergency), body mass index (BMI), site of operation, organisms isolated and associated risk factors ( e.g diabetes) were obtained and recorded on a data sheet. 
SSIs were diagnosed according to the guidelines of the Centre for Disease Control and Prevention, Atlanta $1999^{7}$. An operation was defined as any procedure involving skin incision undertaken in an operating theatre under any type of anaesthesia. Swabs were taken from infected surgical sites and routinely from non infected areas. The specimens were gram stained and examined for the presence of micro organisms and cultured aerobically and anaerobically on blood agar as well as in cooked meat broth.Data were analyzed using SPSS version 16. Chi square $\left(\mathrm{x}^{2}\right)$ and Fisher's exact tests were used to observe associations. $\mathrm{P}$ value of $<0.05$ was considered statistically significant.

\section{Results}

There were 32 cases of surgical site infection out of the 350 surgeries within the study period and this constitutes about $9.1 \%$. There were $20(62.5 \%)$ males and 12 females $(37.5 \%)$ with a male to female ratio of 1.7:1.Their ages ranged from 27 to 65 years with a mean of $40.4 \pm 3.7$ years. The age distribution is as shown in table 1 . The most commonly affected age group was 21-30 years but there was no statistical difference in the different groups affected $(\mathrm{P}=0.46)$.SSI was significantly higher in in emergency than elective operations $(\mathrm{P}=$ $0.03)$. There was significantly higher incidence of SSI in patients who had prolong surgeries lasting 2 hours or longer $(21.5 \%)$ than those with shorter surgery time $(4.7 \%)$. P value was 0.02 .

The rate of SSI was higher in dirty wounds $(48 \%)$ compared to contaminated (13.3\%), clean contaminated $(7.9 \%)$ and clean $(0.03 \%)$. P value was 0.04 .Obese patients (BMI $\geq 30)$ had a significantly higher rate of SSI $(\mathrm{P}=0.03)$. See table 1.Table 2 shows the total number of bacterial isolates from the surgical sites of patients recruited for this study. The commonest organism isolated was Klebsiella (37.4\%) followed by Staphylococcus Aureus and Pseudomonas (18.8\% each). The rate of diabetic patients with SSI of $6.25 \%$ was slightly higher than those without SSI $(5.7 \%)$. However, the difference was not statistically significant $(\mathrm{P}=$ $0.12)$.

Table 1: Factors Associated With Surgical Site Infection (Ssi)

\begin{tabular}{|c|c|c|c|c|c|}
\hline $\mathrm{S} / \mathrm{N}$ & Characteristics & $\begin{array}{l}\text { No Of Patients } \\
\text { Ssi/Total }\end{array}$ & & Percentage $\%$ & P Valve \\
\hline 1 & $\begin{array}{r}\text { Age (Yrs) } \\
21-30 \\
31-40 \\
41-50 \\
51-60 \\
61-70\end{array}$ & & $\begin{array}{l}12 / 94 \\
6 / 84 \\
8 / 78 \\
2 / 53 \\
4 / 41\end{array}$ & $\begin{array}{l}12.8 \\
7.1 \\
10.3 \\
3.8 \\
9.8\end{array}$ & 0.46 \\
\hline 2 & Nature Of Operation & $\begin{array}{l}\text { Elective } \\
\text { Emergency }\end{array}$ & $\begin{array}{l}13 / 204 \\
19 / 146\end{array}$ & $\begin{array}{l}6.4 \\
13.0\end{array}$ & 0.03 \\
\hline 3 & Duration Of Surgery & $\begin{array}{l}<2 \mathrm{yrs} \\
>2 \mathrm{yrs}\end{array}$ & $\begin{array}{l}12 / 257 \\
20 / 93\end{array}$ & $\begin{array}{l}4.7 \\
21.5\end{array}$ & 0.02 \\
\hline 4 & Type Of Surgical Wound & $\begin{array}{l}\text { Clean } \\
\text { Clean Contaminated } \\
\text { Contaminated } \\
\text { Dirty }\end{array}$ & $\begin{array}{l}6 / 179 \\
8 / 101 \\
6 / 45 \\
12 / 25\end{array}$ & $\begin{array}{l}0.03 \\
7.9 \\
13.3 \\
48 \\
\end{array}$ & 0.4 \\
\hline 5 & Site Of Operation & $\begin{array}{l}\text { Abdomen } \\
\text { Perineum } \\
\text { Neck } \\
\text { Breast }\end{array}$ & $\begin{array}{l}26 / 240 \\
4 / 42 \\
1 / 18 \\
1 / 50\end{array}$ & $\begin{array}{l}10.8 \\
9.5 \\
5.5 \\
2\end{array}$ & 0.4 \\
\hline 6 & Body Mass Index (Bmi) & $\begin{array}{l}19-24.9 \\
25-30 \\
30\end{array}$ & $\begin{array}{l}19 / 281 \\
8 / 52 \\
5 / 17\end{array}$ & $\begin{array}{l}6.8 \\
15.3 \\
29.4\end{array}$ & 0.03 \\
\hline
\end{tabular}

Table 2: Bacteria Isolates

\begin{tabular}{|l|cl|}
\hline Isolates & No Of Cases & $(\%)$ \\
\hline & 12 & 37.4 \\
\hline Staphylococcus Aureus & 6 & 18.8 \\
\hline Pseudomonas & 6 & 18.8 \\
\hline Escherichia Coli (E.coli) & 4 & 12.5 \\
\hline Mixed (E.coli and Staph) & 4 & 12.5 \\
\hline
\end{tabular}

Table 3: Diabeties Versus Surgical Site Infection

\begin{tabular}{|l|l|ll|l|}
\hline & With Ssi (\%) & \multicolumn{2}{|l|}{ Without Ssi (\%) } & P Valve \\
\hline Diabetics & $2(6.25)$ & 18 & $(5.7)$ & 0.16 \\
\hline Non Diabetics & $30(93.75)$ & 300 & $(94.3)$ & \\
\hline Total & 32 & 318 & & \\
\hline
\end{tabular}




\section{Discussion}

Out of the 350 patients recruited for this study, $9.1 \%$ had SSI, a rate that is similar to the findings of previous studies in Nigeria ${ }^{3,4}$. The male preponderance $(62.5 \%$ of cases) is also in agreement with the findings of others ${ }^{10}$.

The rate of SSI in this study was highest in the age group 21-30 years. Khairy et $\mathrm{al}^{11}$ in their study reported 12-19 years as the most commonly affected age group followed by 20-29. The reason for this difference could be attributed to the exclusion of all paediatric surgical patients from this present study. Astagneau et $\mathrm{al}^{12}$ in their study showed a predominance of SSI inpatients above 65 years compared to those below this age. Although, more than $15 \%$ of of our patients were over 60 years, the SSI rate was low $(7.5 \%)$ in this group. This could be due to the type of operations performed in each study population.

In this study, the rate was significantly higher in emergency operations compared to elective surgeries (13.0\% versus $6.4 \%, \mathrm{P}=0.03)$. Similar findings were reported in other studies ${ }^{11,12}$. This could be due to the fact that most emergency surgeries lack the routine pre operative preparations and also involve contaminated surgeries such as bowel and perianal regions.Similar to previous studies ${ }^{13,14}$, the rate of SSI is highest in dirty wounds followed by contaminated, clean contaminated and clean wounds in descending order.Just like previous studies $^{15,16}$, there is a significant association between obesity and SSI. Obesity has been implicated as a potential source for the increased incidence of SSI ${ }^{17}$. The suggested pathophysiology includes decreased oxygen tension within surgical wounds, impaired tissue penetration of perioperative antibiotics, prolong operation times, increased operative blood loss and obesity related diminished immune function ${ }^{17}$.

Gram negative bacilli (Klebsiella, Pseudomonas and Escherichia coli) were the commonest organisms cultured in this study which reflects the predominance of SSI in abdominal and perineal operations. An operation duration of longer than 2 hour has been reported to be associated with $\mathrm{SSI}^{18,19}$. This was demonstrated in this study where operation of more than 2 hours was significantly associated with SSI ( $\mathrm{P}=$ 0.02). This could be due to the increased duration of exposure to micro organisms in the operating theatre. In contrast to other studies ${ }^{11,20}$, this study did not find any significant association between diabetes and SSI. The low number of cases in this study may have been responsible for this variation.

\section{Conclusion}

The rate of SSI was $9.1 \%$ and the identified risk factors were emergency operations, dirty wounds, long duration of surgery ( $>2$ hours) and obesity.The commonest organism isolated was Klebsiella.

\section{References}

[1]. Awad SS, Palacio CH, Subramanian A, Byers PA, Abraham P, Lewis D et al. Implementation of a methicillin- resistant staphylococcus aureus (MRSA) prevention bundle results in MRSA surgical site infection. Am J Surg 2009; 198: 607-610.

[2]. Aderson DJ, Sexton DJ, Kanafani ZA, Auten G, Kaye KS. Severe surgical site infection in community hospitals: epidermiology, key procedures and the changing prevalence of methicillin-resistant staphylococcus aureus. Infect Control Hosp Epidermiol 2007; 28: 1047-1053.

[3]. Oni AA, Ewete A, Gbaja AT, Folade AF, Mutiu WB, Adeyemo DA et al. nosocomial infection: surgical site infection in UCH Ibadan, Nigeria. Nig J Surg Res 2006; 8: 19-23.

[4]. Jido TA, Garba ID. Surgical site infection following cesarean section in Nigeria. Ann Med Health Sci Res $2012 ; 2: 367-371$.

[5]. Kirty JP, Masuzi JE. Prevention of surgical site infection. Surg Clin N 2009; 89: 365-389.

[6]. Perencevich EN, Sands KE, Cosgrove SE, Guadagnoli E, Meara E, Platt R. Health and economic impact of surgical site infections diagnosed after hospital discharge. Emer Infect Dis 2003; 9: 196-203.

[7]. Mangram AJ, Horan TC, Pearson ML, Silver LC, Jarvis WR. Guidelines for prevention of surgical site infection. Infect Control Hosp Epidermiol 1999; 20: 250-278.

[8]. Canthon CA, Stemper ME, Schwan WR, Hoffman MA, Qutaishat SS. Significant pathogens isolated from surgical site infection at a community hospital in the mid west. Am J Infect Control 2006; 34; 526-529.

[9]. Jernigan JA. Is the burden of staphylococcus aureus among patients with surgical site infection growing? Infect Control Hosp Epidermiol 2004; 25: 457-460.

[10]. Tanner J, Khan D, Aplin C, Ball J, Thomas M, Bankart J. Post-discharge surveillance to identify colorectal surgical site infection rates and related costs. J Hosp Infect 2009; 72: 243-250.

[11]. Khairy GA, Kambal AM, Dohayan AA, Al-Shehri MY, Zubaidi AM, Al-Naami MY, et al. surgical site infection in a teaching hospital: A prospective study. J Taibah Univ Med Sci 2011; 6: 114-120.

[12]. Kamat US, Fereira AMA, Kukarni MS, Mothgane DD. A prospective study of surgical site infections in a teaching hospital I Goa. Indian J Surg 2008; 70: 120-124.

[13]. Szilagyi E, Borocz K, Gasmuer P, Kurez A. The national nosocomial surveillance network in Hungary; results of two years surgical site infection surveillance. J Hosp Infect 2009; 71: 74-80.

[14]. Rosenthal R, Weber WP, Marcel Z, Misteli H, Reck S, Oertli D, et al. impact of surgical training on incidence of surgical site infection. World J Surg 2009; 33: 1165-1173.

[15]. Mullen JT, Moorman DW, Davenport DL. The obesity paradox; body mass index and outcomes in patients undergoing non bariatic general surgery. Ann Surg 2009; 250: 166-172.

[16]. Dindo D, Muller MK, Weber M, Clavien PA. Obesity in general elective surgery. Lancet. 2003; 361: 2032-2035.

[17]. Hourigan JS. Impact of obesity on surgical site infection in colon and rectal surgery. Clin Colon Rectal Surg 2011; 24: 283-290.

[18]. Leong G, Wilson J, Charlett A. Duration of operation as a risk factor for surgical site infection: comparison of English and US data. J Hosp Infect 2006; 63: 255-262. 
[19]. Ercole FF, Starling CE, Chianca TC, Carneiro M. Applicability of the national nosocomial infection surveillance system risk index for the prediction of surgical site infection: a review. Braz J Infect Dis. 2007; 11; 134-141.

[20]. Neumayer L. Hosokawa P, Itani K, El-Tamer M, Henderson WG, Khuri SF. Multivariable predictors of post operative surgical sit infection after general and vascular surgery: Results from the Patient Safety in Surgery Study. J Am Coll Surg 2007; 204: 11781187. 